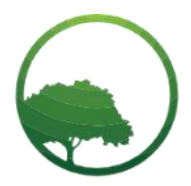

Research in Business \& Social Science

IJRBS VOL 10 NO 7 ISSN: 2147-4478

\title{
Influence of corporate governance on performance of public universities in Kenya
}

\author{
(D) Peter Kariuki ${ }^{(a) *}$ (iD Beatrice Ombaka (iD Paul Kiumbe \\ (a) School of Business, Department of Human Resource Development, Karatina University, P.O. BOX 1957 -10101, Karatina, Kenya \\ (b) Lecturer, School of Business, Department of Human Resource Development, Karatina University, P.O. BOX 1957 -10101, Karatina, Kenya \\ ${ }^{(c)}$ Lecturer, School of Business, Department of Business and Economics, Karatina University, P.O. BOX 1957 -10101, Karatina, Kenya
}

\begin{tabular}{l} 
A R T I C L E I N F O \\
\hline Article history: \\
Received 11 September 2021 \\
Received in rev. form 16 Oct. 2021 \\
Accepted 23 October 2021 \\
Keywords: \\
Corporate Governance, Transparency, \\
Adherence to Management \\
Guidelines, Public Participation, \\
Performance, Public Universities \\
JEL Classification: \\
O15
\end{tabular}

\begin{abstract}
A B S T R A C T
This study aims to determine the influence of corporate governance on performance of Public Universities in Kenya. The study was anchored on social network theory. To achieve the objective, the study was based on a pragmatic philosophy and mixed research design with a target population of 234 University top managers. Primary data was collected using a 5 point Likert type questionnaire and an interview guide. Data was analyzed using descriptive and inferential statistics. Findings revealed that corporate governance had significantly statistical influence on performance of public universities in Kenya. This study concluded that adherence to good corporate governance practices are essential strategies Public Universities can use in their endeavour to improve on their performance. It is further recommended that University top managers should adhere to good corporate governance practices, specifically to management guidelines, allow for public participation and be transparent in their actions. Further, the results present important implications to University top managers, other corporate entities, policy makers, and stakeholders in the University education sector in Kenya and across the world.
\end{abstract}

(C) 2021 by the authors. Licensee SSBFNET, Istanbul, Turkey. This article is an open access article distributed under the terms and conditions of the Creative Commons Attribution (CC BY) license (http://creativecommons.org/licenses/by/4.0/).

\section{Introduction}

Corporate governance practices have been advocated over the centuries (McNutt, 2010). However, the concept gained prominence in the nineteenth century, especially the 1980s, following a series of corporate collapses, board level excesses and detrimental effects of dominant chief executives (Tricker, 2011). As a result, various governments sought to use legislations to reverse this trend and to improve the governance of corporations (Vinten, 2001). Notable legislations include the (Companies Act, 2015) enforced by Capital Market Authority, (Corporate Governance Council, 2007), the (Cadbury, 1992) Report and the FRC (2010). An analysis of these legislations indicates that they advocate the need for transparency, adherence to management guidelines, public participation and governance matters in a timely and accurate manner. They also advocate the effective monitoring of management teams and making boards accountable for their activities, dealing with employees fairly, making decisions responsibly, maximizing the value of assets, operating ethically and recognizing the legitimate interests of stakeholders (Petra, 2006).

According to Mwiria (2007), University education in regard to corporate governance is said to involve the management to make corporate decisions about key policies and practices in several critical areas concerning the University: their number and location, their mission, their enrolment size, the access of students to their instructional programmes and the access of citizens to other services, degree requirements, the quality standards expected in student performance, the quality of research and public service activities, the freedom available to individual faculty members in their instructional and research activities, the appointment of staff, internal organizational structure and the allocation of available resources. Compliance to set rules, guidelines and policies the university has set forth ensure trust and loyalty of the stakeholders for productivity (Millet, 1995).

* Corresponding author. ORCID ID: 0000-0002-2058-1557

(C) 2021 by the authors. Hosting by SSBFNET. Peer review under responsibility of Center for Strategic Studies in Business and Finance. https://doi.org/10.20525/ijrbs.v10i7.1402 
The Kenyan Public Universities are currently faced with major challenges that include an uncertain future stability, political changes and a globalized market (Nafukho, 2008). Specifically, they encounter challenges that relate to the rapid expansion of University education, reduced government funding, gender inequality, low research capability, students living in poor conditions and the spread of HIV/AIDS (Mwiria and Ng'ethe, 2007). As a result of these challenges, there is need for reforms in the management of the said institutions and (Mwiria 2007) highlights corporate governance as the area most in need of reform.

Kenya's public University system has experienced very high rates of growth which have not been accompanied by a commensurate rise in the level of funding. This growth of Universities in the face of budgetary deficits and manpower surpluses is largely a product of the insatiable demand for higher and higher levels of education. The government seems to have exploited such demand and politicized decision-making in the expansion of University education whose effect appears to be a serious decline in the performance of Public Universities measured by the research grants, community engagement and completion rate of graduates coupled with acute shortage of facilities and teaching personnel.

\section{Review of Literature}

\section{Theoretical Review}

This study was anchored on social network theory advanced by (William N. Dunn, 1983) to conceptualize the relationship between corporate governance and performance of public Universities in Kenya. The theory was found appropriate for the study because of it philosophy and patterns which are based on the interaction among stakeholders and various forms of cooperation between ownership and control as suggested by (Visconti, 2019). According to Shabbir and Padget (2005), social network posits that University setting is complex in nature and the role of strategy in attaining competitive advantage is of paramount importance. Faust (1997) indicate that social network theory is a sociology-based theory that build upon the relational dimension. It is built on the conceptualization of nodes, the actors in a network, and ties, and the relations existing between those actors. The theory is grounded in three principles. First, the behaviour of a node is influenced by the behaviour of other nodes in the network. This means that nodes do not act independently from one another, they are mutually dependent. Second, the ties between nodes form the basis for the exchange of both goods and ideas. In other words, the ties channel the transmission of information through the network. Third, these ties have the ability to create structures among the actors in the network that can influence their behaviour (Wasserman and Faust, 1994). The theory links to corporate governance issues for instance ownership structure and the link between many or few nodes of shareholders with the University and other stakeholders (Faust, 1997). Each shareholder represents a node that is linked to other edges with other nodes. Nodes have different degree of importance (Visconti, 2019). Figure 1 below show different social networks that exist in the Universities.

Figure: 1-University External and Internal Stakeholder's Network

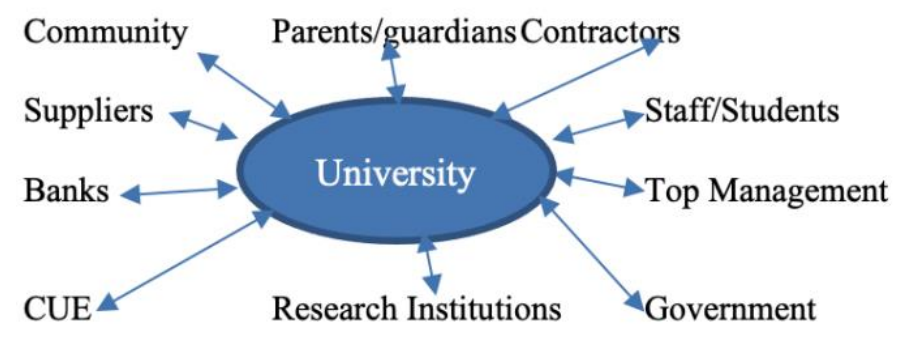

Figure 1: University External and Internal Stakeholder's Network; Source: Author (2021)

According to Shabbir and Padget (2005), the social network theory emphasizes socialization and teamwork that result to strong internal corporate governance structures that help improve University performance. It holds that there is need for the setting up of rules and incentives to align the behaviour of managers to the desires of owners (Hawley and Williams, 1996), thus it determines the governance mechanisms to be adhered through formulation of codes of corporate governance in order to reduce firm conflicts and attain wealth maximization through enhanced performance. The social network theory therefore enriched the study by creating an understanding of the need to adhere to management guidelines, being transparent and people involvement in decision making for superior University performance. Social network theory acknowledges that Universities do not only exist merely to teach, but has a responsibility to serve a wider social purpose and interests (Donaldson and Preston, 1995). Thus, there is need to take all their interests into consideration while making corporate strategic decisions (Freeman, 1984 a; 2010 b; Lawal, 2012). It argues that Universities are expected to extend their fiduciary duty and social responsibility to the local community and the environment in which they operate (Freeman, 1984) hence providing a mechanism for collaborations. As such, corporations that conscientiously strive to serve the interests of all stakeholders build more value overtime translating to high performance (Freeman, 1984; Harrison and Wicks, 2013). The social network theory therefore is useful in the study for promoting an understanding of the relationship between University 
stakeholders and the overall University performance. Even through both corporate governance and network science are well grounded theories, their possible connection has been hardly investigated (Vermeulen ,2015).

\section{Empirical Review}

According to a study by Waduge (2011) while examining the association between corporate governance and University performance, so far point to a lack of consensus on the effect of corporate governance on university performance. The finding is attributable to the existing conceptual, empirical and theoretical gaps inherent in the studies, thus making it hard to form a conclusive opinion as to whether there truly exist some reliable linear relationships between the two variables. Evidence in the empirical literature is largely contradictory and debatable. A study by Sibanda (2017) among 37 Australian Public Universities to examine the relationship between governance structures, practices and the performance of the University sector using data from annual reports of the Universities and other University education sector bodies found mixed results on the relationship between various aspects of corporate governance and performance of the Universities. Establishment of council committees was found to have a strong positive relationship with overall research and financial performance of the Universities (Sibanda ,2017).

A cross sectional descriptive survey by Tusubira and Nkote (2013) examined the relationship between corporate governance and financial performance among private universities in Uganda revealed that council and senate size negatively affected the financial performance of private Universities while policy and decision making were found to significantly affect the financial performance of the Universities measured by actual revenue/budget revenue ratio and actual expenditure/budget expenditure ratio. A related study by Ndiwalana, Ssekakubo and Lwanga (2014) among 59 savings, credit and cooperative societies in the same country found that corporate governance did not have any effect on the financial performance of savings, credit and cooperative societies in Uganda and therefore the study concluded that there is no relationship between corporate governance and firm performance, effectively demonstrating inconsistency with the conclusions made by (Tusubira and Nkote ,2013) among other researchers.

To establish the impact of corporate governance on firm competitiveness and performance among SMEs in South Africa, (HoveSibanda and Pooe, 2017) conducted a cross sectional research study that revealed that implementation of corporate governance among SMEs positively and significantly affected their performance. Also conducted in South Africa is a study by Mashonganyika (2015) to examine the impact of corporate governance on performance of publicly listed firms on the (Johannesburg Stock Exchange (JSE) in South Africa between 2009 and 2013. Using return on asset (ROA), return on equity (ROE) and Tobin's Q as proxies for firm performance, the study found that board size as an aspect of corporate governance did not have any impact on firm performance. Frequency of board meetings, board gender and age diversity, board independence and CEO non-duality were however found to have significant effect on performance of publicly listed firms on the Johannesburg Stoke Exchange (Mashonganyika, 2015).

Ndwiga (2018) conducted a cross sectional research study in Kenya among 56 companies listed on the Nairobi Securities Exchange to investigate the relationship between corporate governance and firm performance among the listed companies. Using board size, board gender diversity and CEO duality, board Leadership, board ethics and operations as proxies of corporate governance, regression analysis results revealed that corporate governance had positive relationship with firm performance. Firm performance was measured by Tobin's Q, return on assets (ROA), return on equity (ROE), equity per share (EPS) and other non-financial performance indicators such as customer satisfaction, learning and growth and internal processes.

Another study by Kamau (2018) using both descriptive and explanatory research designs among 162 financial institutions in Kenya to establish the influence of corporate governance on firm performance revealed that corporate governance overall, corporate governance had a significant influence on firm performance. Individual components of corporate governance however produced mixed results regarding their influence on firm performance. Board skills and committees were found to have significant and positive influence on performance of the financial institutions while board independence, board size, board diversity and codes of corporate governance (accountability, transparency, ethics, and fairness) were found to have no significant influence on firm performance among the financial institutions, thus demonstrating inconsistencies and similarities with other studies in equal measure. Firm performance was conceptualized in terms of financial soundness, customer focus, internal business processes, social equity, learning and growth and environmental consciousness. Also producing mixed results is a cross-sectional study conducted among 47 companies listed on the Nairobi Stock Exchange to establish the relationship between board of directors' attributes, strategic decisionmaking and corporate performance by (Letting ,2011) where the effect of various board attributes on corporate performance was assessed.

Another study by Okoko (2017) to investigate the relationship between corporate governance and firm performance among 40 insurance companies in Kenya revealed using panel data that overall, there exists a relationship between corporate governance and firm performance. Various attributes of the board however produced varying nature of relationships with firm return on assets used as the measure of performance. Board composition and frequency of board meetings were found to have positive relationship with performance while board size showed a negative relationship with firm performance among the insurance companies. Based on the reviewed literature, it is evident that there exists empirical literature on corporate governance from previous research work. However, the study notes that the literature available is limited and previous scholars have measured corporate governance against other variables in limited scope such as innovation performance, operational performance, financial performance, board size and growth. The study also notes that most of studies conducted were among financial institutions such as commercial banks and insurance 
companies but no known study has linked corporate governance and performance of public Universities. Hence, the study hypothesized that;

$H_{0}$ : There is no significant influence of corporate governance on performance of Public Universities in Kenya

\begin{tabular}{|c|c|}
\hline $\begin{array}{l}\text { Dependent Variable } \\
\text { Corporate Governance }(\mathrm{X}) \\
\text { 1. Level of Transparency } \\
\text { 2. Adherence to management Guidelines } \\
\text { 3. Level of public Participation }\end{array}$ & $\begin{array}{l}\text { Independent Variable } \\
\text { Performance of Public University (Y) } \\
\text { 1. Completion rate of graduates } \\
\text { 2. Attraction of research grants } \\
\text { 3. Community engagement }\end{array}$ \\
\hline
\end{tabular}

Figure 2: Conceptual Framework; Source: Author, 2021

\section{Research and Methodology}

This study adopted a pragmatic research paradigm as the main philosophical underpinning. This paradigm assumes that knowledge arises from actions, situations, and consequences rather than antecedent conditions (Creswell, 2012). According to Morgan (2007) and Patton (2002), this philosophical underpinning is deemed fit as it allows mixed methods approach by permitting the researchers freedom to choose the methods, techniques, and procedures of research that best meet the needs and purposes of the research problem in question. The study adopted mixed method research and in particular convergent parallel design. The design enabled the researcher to simultaneously collect both quantitative and qualitative data, merge the data, and use the results to understand the research problem Creswell and Plano Clark (2011). The study surveyed (234) public chattered Universities in Kenya. Primary data was obtained through semi structured questionnaires and an interview guide which was tested for validity using content validity and reliability internal consistency via Cronbach's alpha coefficient $(\alpha)$ respectively. The questionnaire was designed on a five point Likert -type scale ranging from (1) - strongly disagree to (5) - strongly agree (Sekaran and Bougie, 2017); (Saunders, et al. 2017). Moreover, Pilot testing was done to ensure that the research tool was valid and reliable and also to improve its face validity (Cooper and Schilder, 2011). The target respondents were Vice Chancellor, Deputy Vice Chancellors, Registrars, Finance Officers and Quality Assurance Officers because they were best placed to answer the research questions.

In this study, data was analysed using descriptive statistics such as frequencies, means and standard deviation and presented inform of tables as well as inferential analysis using measures such as correlation and multiple regression analysis to establish the nature and magnitude of the relationships between the variables (Jobson, 2012). Correlation analysis was carried out to determine the nature and strength of the relationship that exist among the study variables (Glesne, 2015) while regression analysis was conducted using linear and multiple regression models to determine the extent to which corporate governance affect performance of public universities in Kenya. The multiple regression model was as follows.

\section{Equation}

$$
Y=\beta_{0}+\beta_{1} X+\varepsilon
$$

Where

Y- Performance of public universities, $\beta_{0}=$ The intercept, $\beta_{3}=$ Regression coefficients shows the change in the value of $Y$ from a unit change in $\mathrm{X}, \mathrm{X}$ - level of adherence to Corporate governance, $\varepsilon=$ Random error

\section{Results and Discussions}

The study used descriptive and inferential statistics to make conclusions on the relationship existing between the study variables. The descriptive statistics provides a summary on the characteristics of the study variables through measures of central tendency: specifically, the mean and the standard deviation. Corporate governance was operationalised through, transparency, adherence to management guidelines and public participation as advised (Garaika, Siswoyo and Zainal ,2018). The descriptive results were as shown in Table 1.

\section{Descriptive Statistics}

In order to establish responses made to the research items, the mean and standard deviation were determined. The mean gave indications on the average direction of the variables for each construct, while the standard deviation provided information on the level of dispersion from the mean. A low standard deviation meant that most of the responses group were around the mean. 


\section{Adherence to Corporate Governance Practices}

Descriptive analysis for the composite variable of corporate governance on transparency, adherence to management guidelines and public participation on performance of public universities is discussed and then subjected to simple regression analysis. The results are presented in table 1.

Table 1: Descriptive Analysis- Adherence to Corporate Governance Practices

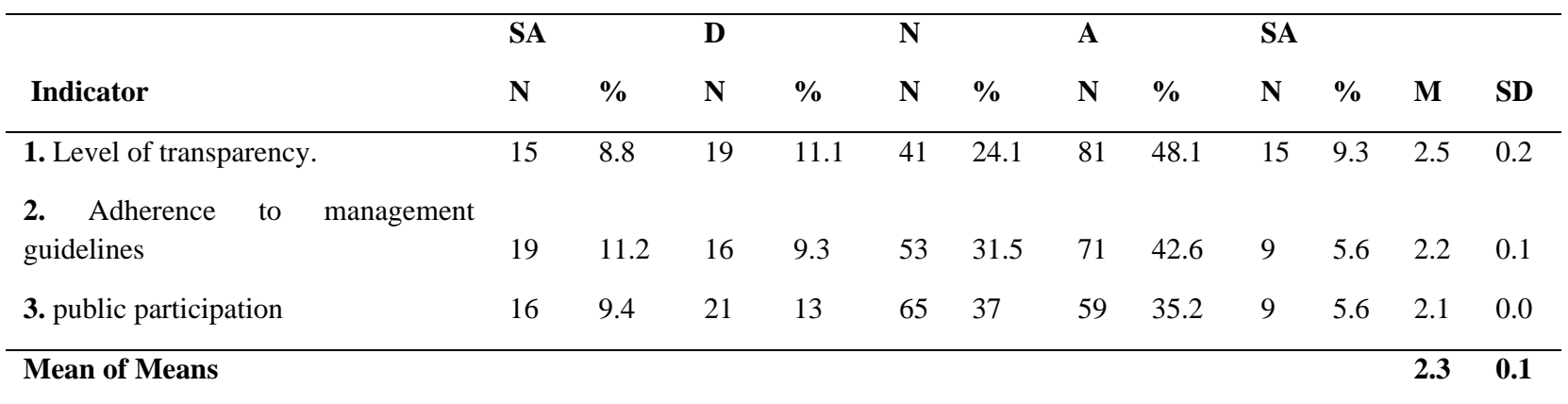

Source: Field Data (2021)

The results in table 1 recorded a mean score of 2.5 and a standard deviation of 0.2 on transparency. The study found out that the respondents agreed that the Public Universities were average on transparency. Indicator two assessed whether the Public Universities adhere to management guidelines. The results recorded a mean score of 2.2 and a standard deviation of 0.1 . The study found out that the respondents disagreed that the Public Universities adhere to management guidelines. Indicator three assessed the level of public participation in Public Universities. The results recorded a mean score of 2.1 and a standard deviation of 0.0. The study found out that the respondents disagreed that there was public participation in Public Universities. The study commuted the mean of means of the three indicators that extricated the level of adherence to corporate governance practices. The mean of mean was 2.3 and a standard deviation of 0.1 . The results indicated that the level of adherence to corporate governance practices was low. The results of the study are consistent with the findings by (Agiri, 2020) that Universities in Kenya have not put in place enough emphasis on accountability, transparency and ethics mechanisms meant to institutionalize corporate governance to propel effective performance of the Universities. Corporate governance among Kenyan Universities is still generally weak and therefore require strengthening because it is positively and significantly related to University performance and that corporate governance significantly affects performance of universities in Kenya. Further, collaborated by observations of (Monyoncho, 2015) that lack of transparency in Kenyan Universities had created fertile grounds for corrupt and unethical tendencies and inefficiencies in the appointment and selection of University leaders and delivery of academic programmes which in turn negatively impacted on performance of the institutions in general. Rockoff and Turner (2010) found that a transparent system that evaluated schools based on a set of continuous metrics with focus on mathematics and English subjects significantly increased student achievement in Math and English.

In light of these revelations, the study finds that public universities in Kenya would benefit immensely if they adhere to corporate governance practices on being transparent, adhering to management guidelines and allow for public participation in decision making including the processes and sharing this knowledge across the firm.

\section{Descriptive Statistics- Performance of Public Universities}

Table 2: Performance of Public Universities

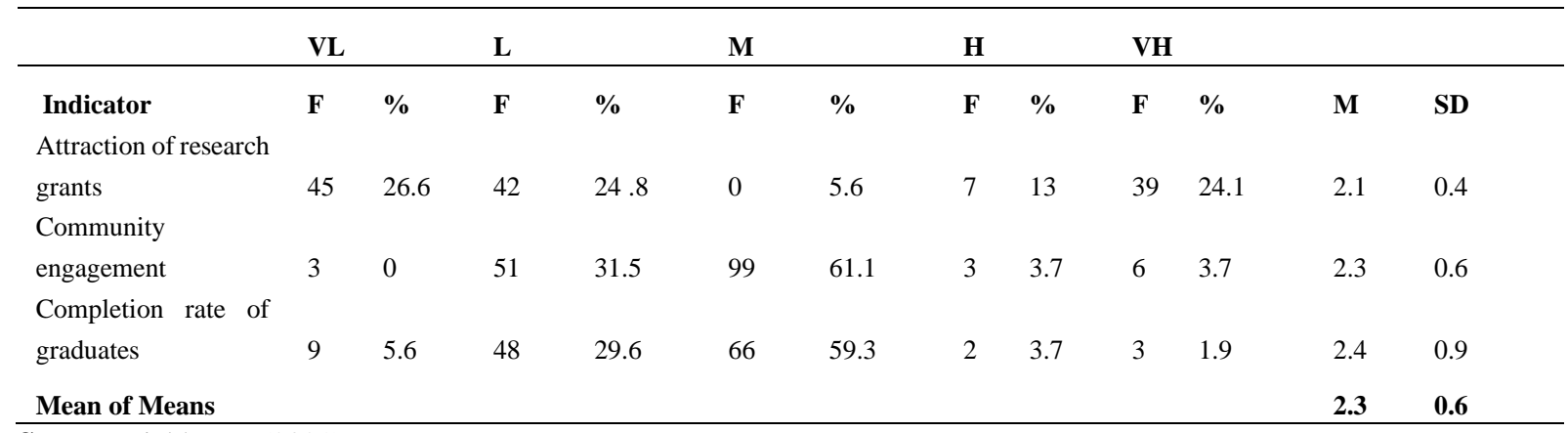

Source: Field Data (2021)

Table 2 assessed the attraction of research grants in the Public Universities. The results recorded a mean score of 2.1 and a standard deviation of 0.4. The study found out that the respondents agreed with the fact that the research grant in Public Universities was low. Indicator two assessed community engagement in Public Universities. The results recorded a mean score of 2.3 and a standard deviation of 0.6. The study found out that the respondents agreed with the fact that the community engagement in Public Universities was low. Indicator three assessed the completion rate of graduates in Public Universities. The results recorded a mean score of 2.4 
and a standard deviation of 0.9. The study found out that the respondents agreed with the fact that the completion rate of graduates in Public Universities was average. The study computed the mean of means of the three items that extricated the performance of Public Universities. The mean of means was 2.3 and a standard deviation of 0.6. The results indicated that the level of performance of Public Universities was low. This low performance by Public Universities were clearly explained by some key responses. For instance, some had this to say about the performance of their universities.

"We are not doing well on performance, The Code of Conduct and Ethics for Public Universities 2003, for example states that: "An officer who is a member of the academic staff of a University shall organize his/ her instruction, assessment and examination in a manner that complies with all institutional requirements and expectations. And, an officer who is a member of the academic staff of a university shall ensure that the examinations are delivered to the students as scheduled and that the result thereof is processed without undue delay. You see, all this has to do with adherence to rules and regulations set by the university. Transparency in the process and having members of staff and key stakeholders participate in decision making is very important". (Key Respondent 1)

The findings are consistent with Odhiambo (2014) who observes that the performance of Public Universities in Kenya for sustainability attracts divergent responses from different people. Some argue that higher education yields huge dividends and thus should be financed privately, while others perceive it as a public good that ought to be funded by the state. Prior to 1970, the Kenyan government paid fully for University education (Munene and Otieno ,2008). The idea was to create a highly trained workforce that could replace the departing colonial administrators and which was achieved by bonding the graduates to work in the public service for three years (Nafuko ,1995). However, (Wangenge ,2015) points out that the poor performance by Kenyan Public Universities was a result of change to the free model of financing University education in Kenya that soon proved unsustainable amid rising demand and the economic difficulties of the early 1970s caused by soaring oil prices. The model triggered a paradigm shift in which cost-sharing was introduced in the 1974/75 academic year in the form of loans given to students for meeting personal expenses while the government continued paying for tuition. In 1988, further cost-sharing was introduced on tuition fees following high pressure sustained on the government by supranational institutions namely the World Bank (WB) and International Monetary Fund (IMF).

\section{Reliability of the Research Instruments}

Reliability of the research instrument in this study was tested using internal consistency test. The internal consistency was measured using Cronbach's alpha coefficient $(\alpha)$ which indicates how well the items in a set are positively correlated to one another (Nunally, 1978). The study calculated the reliability of the study variables and the results are as shown in Table 3.

Table 3: Validity and Reliability Analysis

\begin{tabular}{lllll}
\hline Variables & Measures & $\begin{array}{l}\text { Number } \\
\text { Dimensions }\end{array}$ & $\begin{array}{l}\text { of Cronbachs' } \\
\text { Alpha }\end{array}$ & Comments \\
\hline Corporate & Transparency & 10 & 0.806 & Reliable \\
Governance & Adherence to management & 5 & & \\
Total & Public participation & 6 & & \\
Performance & Completion rate of graduates & 3 & 0.787 & Reliable \\
measures & Attraction of research grants & 3 & & \\
& Community outreach & 3 & & \\
Total & & $\mathbf{9}$ & & \\
\hline
\end{tabular}

Source: Researcher (2021)

The results in Table 3 show that Chronbach's Alpha coefficient ranged between 0.787 (performance measures) and 0.806 (corporate governance). The results indicate that measurement scales used were sufficiently reliable and measured the study variables adequately. The reliability coefficient for all the constructs used in this study by far exceeded the 0.5 minimum level of acceptability recommended by (Hair et al., -1998) and are above the 0.7 range advocated by (Nunally, 1978); thus are reliable and acceptable for further analysis. The study constructs were highly correlated to each other.

\section{Results}

The objective of the study was to establish the influence of corporate governance on performance of public universities in Kenya. First, the influence of individual variables of corporate governance that is transparency, adherence to management guidelines and public participation on performance of public universities in Kenya was tested. This followed composite indicator of corporate governance and effect on the performance of public Universities.

According to results in table 4, R2 was 0.319 meaning that $31.9 \%$ of variance in performance accounted for by the level of transparency. $68.1 \%$ was explained by other factors not considered in the study. 
Table 4: Regression Results for the Effect of Transparency on Performance of Public Universities.

Coefficients

\begin{tabular}{|c|c|c|c|c|c|c|c|}
\hline \multirow[t]{3}{*}{ Model } & \multirow{2}{*}{\multicolumn{2}{|c|}{ Unstandardized Coefficients }} & \multirow{2}{*}{$\begin{array}{l}\text { Standardized } \\
\text { Coefficients }\end{array}$} & \multirow[t]{3}{*}{$\mathrm{t}$} & \multirow[t]{3}{*}{ Sig. } & \multirow{2}{*}{\multicolumn{2}{|c|}{$\begin{array}{l}95.0 \% \text { Confidence } \\
\text { Interval for B }\end{array}$}} \\
\hline & & & & & & & \\
\hline & B & Std. Error & Beta & & & Lower Bound & Upper \\
\hline (Constant) & 1.860 & .132 & & 14.07 & .000 & 1.600 & 2.120 \\
\hline Level of Transparency & .377 & .038 & .556 & 10.022 & .000 & .303 & .451 \\
\hline
\end{tabular}

a. Dependent Variable: Performance of Public Universities

Model Summary

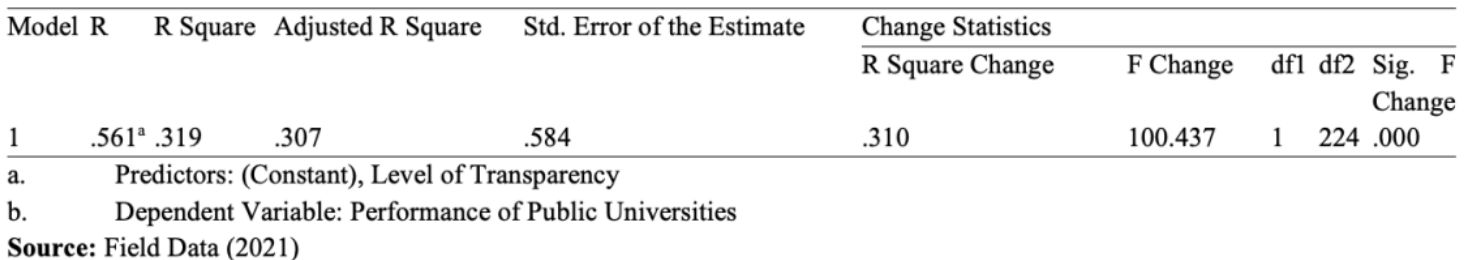

Further, the results revealed statistically significant results for the independent effect of transparency on performance ( $\mathrm{p}$-values < $\left.0.05), \mathrm{R}^{2}=0.319, \mathrm{~F}=100.437, \mathrm{p}<0.05\right)$, indicating goodness of fit for the regression model and producing a statistically significance beta coefficient of $\beta=0.377$, $(t=14.074, p<0.05)$. The results reveal a unit increase in level of transparency is responsible for increasing performance of public Universities by 55.6\%. These can be summarized using the following equation

$$
\mathrm{UP}=1.860+0.377 \mathrm{~T}+\mathrm{e}
$$

The findings are in line the Constitution of Kenya 2010, Chapter 13 (232) on values and principles of Public Service that require all public officers and more so the leaders to be transparent and to provide information to the public in a timely and accurate manner. The Constitution requirement is consistent with the findings by Andrabi et al., (2017) who found that transparency had caused an improvement in learning in public schools in India while an investigation by (Sabas and Mokaya, 2016) on the influence of transparency on students' performance in public secondary schools in Uganda revealed that transparency contributed significantly to student's academic performance which consequently improved school performance ratings. Achoki, Kule and Shukla (2016) found that voluntary disclosure of financial information to stakeholders had a positive effect on performance among commercial banks.

Study by Makanyeza, Kwandayi and Ikobe (2013) also reported that lack of transparency and inadequate citizen participation were among the major causes of poor service delivery in County Councils in Kenya. In an intervention that disclosed test scores and admission rates for schools, Hastings and Weinstein (2008) reported that parents were significantly more likely to select highperforming schools against low performing ones, and that their children's test scores increased as a result. Waduge (2011) however found a statistically insignificant relationship between transparency in reporting and performance of among Australian universities, indicating inconsistency of findings regarding the relationship and effect of transparency on organizational performance.

Table 5: Regression Results for the Effect of Adherence to Management Guidelines on Performance of Public Universities

\section{Coefficients}

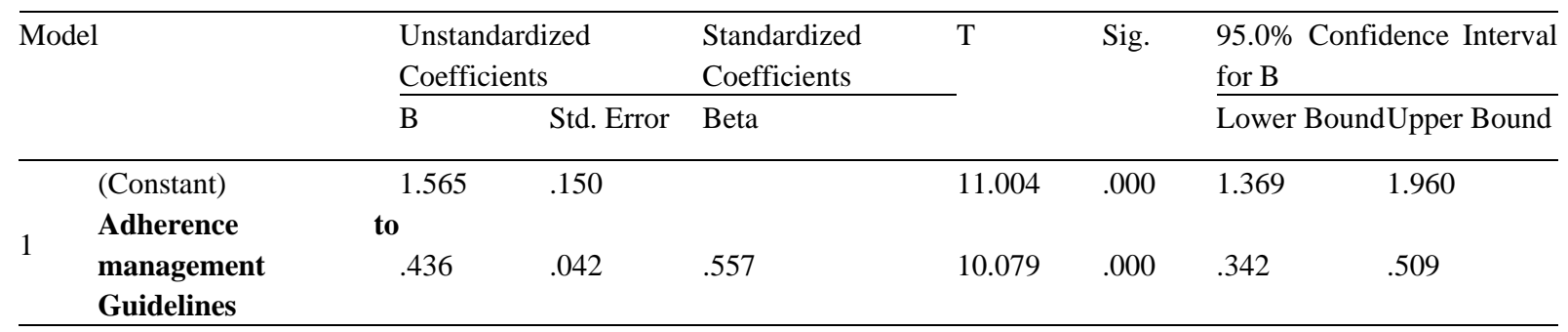

\section{Model}

\begin{tabular}{|c|c|c|c|c|c|c|c|c|c|c|}
\hline \multirow[t]{2}{*}{ Model } & \multirow[t]{2}{*}{$\mathrm{R}$} & \multirow[t]{2}{*}{ R Square } & \multirow{2}{*}{$\begin{array}{l}\text { Adjusted } \\
\text { Square }\end{array}$} & \multirow{2}{*}{$\begin{array}{l}\text { RStd. Error of } \\
\text { Estimate }\end{array}$} & \multicolumn{6}{|c|}{ theChange Statistics } \\
\hline & & & & & $\mathrm{R}$ & SquareF Change & df1 & df2 & Sig. & $\bar{F}$ \\
\hline 1 & $.559^{\mathrm{a}}$ & .312 & .309 & .593 & .312 & 101.589 & 1 & 224 & .000 & \\
\hline
\end{tabular}

a. Predictors: (Constant), Adherence to management guidelines

b. Dependent Variable: Performance of Public Universities 
According to results in table $5, \mathrm{R}^{2}$ was 0.312 meaning that $31.2 \%$ of variance in performance accounted for by the level of adherence to management guidelines. $68.8 \%$ was explained by other factors not considered in the study.

Further, the results reveal statistically significant results for the independent effect of adherence to management guidelines on performance ( $\mathrm{p}$-values $<0.05$ ). $\mathrm{R}^{2}=0.312, \mathrm{~F}=101.589, \mathrm{p}<0.05$ ), indicating goodness of fit for the regression model and producing a statistically significance beta coefficient of $\beta=0.436,(t=11.004, p<0.05$ The results reveal a unit increase in level of adherence to management guidelines is responsible for increasing performance of public Universities by $55.7 \%$. These can be summarized using the following equation.

$$
\mathrm{UP}=1.565+0.436 \mathrm{ADG}+\mathrm{e}
$$

The results in table 5.0 are consistent with the Code of Conduct and Ethics for Public Universities 2003, Cap 193, Part II, 6:1-2 states that: "An officer who is a member of the academic staff of a University shall organize his/ her instruction, assessment and examination in a manner that complies with all institutional requirements and expectations. And, an officer who is a member of the academic staff of a university shall ensure that the examinations are delivered to the students as scheduled and that the result thereof is processed without undue delay". The statement concurs with observations by Kamau, (2017) that cases of admission of students into universities in Kenya without meeting the minimum entry requirements and contracting fellow students to help them do their academic work like writing research theses and projects were as a result of not adhering to management guidelines on admissions and examinations. His findings are reinforced by sentiments from Akaranga (2013) that lack of adherence to management guidelines had caused some students in universities to miss graduation because some academic staff failed to mark their assignments or scripts on time or lost student marks altogether.

Table 6: Regression Results for the Effect of Public Participation on Performance of Public Universities

\section{Coefficients}

\begin{tabular}{|c|c|c|c|c|c|c|c|c|}
\hline \multirow[t]{2}{*}{ Model } & \multicolumn{3}{|c|}{ Unstandardized Coefficients } & \multicolumn{2}{|c|}{ Standardized Coefficients } & \multirow[t]{2}{*}{$\mathrm{t}$} & \multicolumn{2}{|c|}{$\begin{array}{l}\text { Sig. } 95.0 \% \text { Confidence Interval } \\
\text { for B }\end{array}$} \\
\hline & $\mathrm{B}$ & \multicolumn{2}{|c|}{ Std. Error } & \multicolumn{2}{|l|}{ Beta } & & Lower Bound & $\begin{array}{l}\text { Upper } \\
\text { Bound }\end{array}$ \\
\hline (Constant) & 1.897 & \multicolumn{2}{|l|}{.141} & & & \multicolumn{2}{|c|}{14.204 .0001 .720} & 2.274 \\
\hline${ }^{1}$ Public Participation & .345 & \multicolumn{2}{|l|}{.041} & .779 & & \multirow[t]{2}{*}{8.388} & .000 .264 & .426 \\
\hline \multicolumn{8}{|c|}{ a. Dependent Variable: Performance of public universities } & \\
\hline \multicolumn{9}{|c|}{ Model } \\
\hline \multirow[t]{2}{*}{ Model R } & \multirow{2}{*}{\multicolumn{2}{|c|}{ Adjusted R Square }} & \multirow{2}{*}{\multicolumn{2}{|c|}{ Std. Error of the Estimate }} & \multicolumn{4}{|c|}{ Change Statistics } \\
\hline & & & & & \multicolumn{2}{|c|}{ R Square Change } & \multicolumn{2}{|c|}{ F Change df1 df2 Sig. F Change } \\
\hline $.779^{a} .249$ & .226 & & .624 & & .239 & & 224.00 & \\
\hline
\end{tabular}

a. Predictors: (Constant), public participation

b. Dependent Variable: Performance of public universities

Source: Field data (2021)

According to results in table $6, \mathrm{R}^{2}$ was 0.249 meaning that $24.9 \%$ of variance in performance accounted for by the level of public participation. $68.1 \%$ was explained by other factors not considered in the study.

Further, the results reveal statistically significant results for the independent effect of public participation on performance ( $\mathrm{p}$-values $\left.<0.05) . \mathrm{R}^{2}=0.249, \mathrm{~F}=70.360, \mathrm{p}<0.05\right)$ indicating goodness of fit for the regression model and producing a statistically significance beta coefficient of $\beta=0.345$, $(t=14.20, p<0.05)$. The results reveal a unit increase in level of public participation is responsible for increasing performance of public Universities by $77.9 \%$. These can be summarized using the following equation.

\section{$\mathrm{UP}=1.897+0.345 \mathrm{PP}+\mathrm{e}$}

The results in table 6 are in line with the Article 10 of the Constitution that lists public participation as one of the national values and principles of governance that binds all state organs, state and public officers, and all persons in Kenya whenever any of them applies or interprets the Constitution, enacts, applies or interprets any laws, or makes or implements public policy decisions. To operationalize the requirement, the Public Service Commission in 2019 developed framework for public participation. In the policy, public participation is conceptualized as the process by which citizens, as individuals, groups or communities also known as stakeholders, take part in the conduct of public affairs, interact with the state and other non-state actors to influence decisions, policies, programs, legislation and provide oversight in service delivery, development and other matters concerning their governance and public interest, either directly or through freely chosen representatives. 
Further, The Constitution of Kenya promulgated in 2010 restructured and transformed the state-society relations in several positive ways. It states that the country's governance is based on social contract, an arrangement in which the citizens only delegate their power to the government but retain the sovereign power. The Constitution places the citizens at the centre of development and related governance processes; it provides for public participation as one of the principles and values of governance.

The results and the constitution requirements are consistent with observations by (Cooper, 2005) that public participation is the process of engagement in governance, in which people participate together for deliberation and collective action within an array of interests, institutions and networks, developing civic identity, and involving people in governance processes. The importance of public participation cannot be overstated. Its contribution in anchoring democracy is significant because it ensures inclusivity and transparency in the governance process, with citizens and government agencies sharing power among themselves (Arnstein, 1969). It ensures government responsiveness to citizen needs and increases the legitimacy of the government's decisions and institutions. Further, at the individual level, public participation increases patriotism and trust in public institutions. This in turn increases social inclusiveness and social capital (Raimond, 2001), making public participation a process and not a single stand-alone event.

\section{Testing Hypotheses}

The study tested the Hypothesis that there is no significant influence of corporate governance on performance of Public Universities in Kenya.

Table 7: Regression Analysis on Adherence to Corporate Governance Practices

\section{Coefficients}

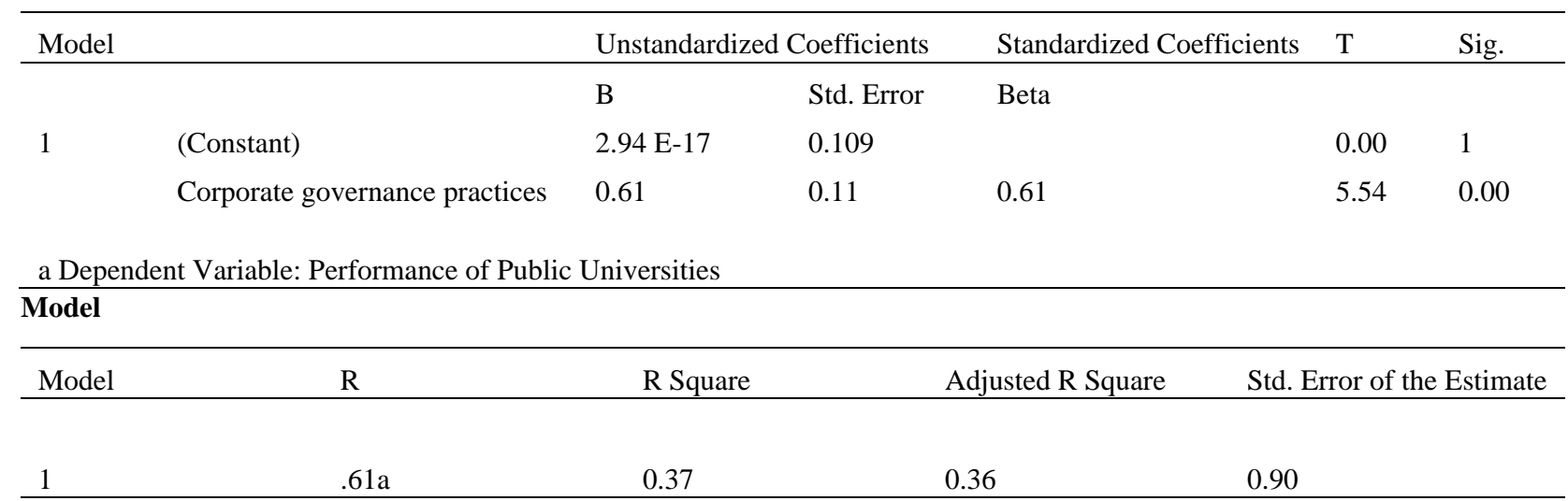

a Predictors: Corporate governance practices

c Dependent Variable: Performance of Public Universities

Source: Field data (2021)

According to results in table $7, \mathrm{R}^{2}$ was 0.37 meaning that $37 \%$ of variance in performance accounted for by the level of corporate governance. $63 \%$ was explained by other factors not considered in the study.

Further, the results reveal statistically significant results for the independent effect of public participation on performance (p-values $\left.<0.05) . \mathrm{R}^{2}=0.37, \mathrm{p}<0.05\right)$ indicating goodness of fit for the regression model and producing a statistically significance beta coefficient of $\beta=0.61,(t=5.54, p<0.05)$. The results reveal a unit increase in level of public participation is responsible for increasing performance of public Universities by $77.9 \%$. These can be summarized using the following equation.

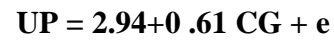

The t-statistic for the regression model was 5.54 which was greater than 1.96 with p less than 0.05 . Therefore, for the hypothesis that there no significant influence of corporate governance on performance of Public Universities in Kenya, the study found the relationship to be statistically significant. Therefore, rejecting the null hypothesis and accepting the alternative hypothesis that there is significant influence of corporate governance on performance of Public Universities in Kenya.

The finding is consistent with those of earlier studies (Ndwiga, 2018; Kamau, 2018; Gregg, 2001; Letting, 2011; Gompers et al., 2003; OECD, 2004; Kiel and Nicholson, 2002) that have reported a positive and significant relationship between corporate governance and organizational performance and found a significant effect of corporate governance on organizational performance. Paramitha, Agustia and Soewarno (2017) also reported a conceptual relationship between corporate governance on performance of Indonesian universities but recommended that a study to establish whether such a relationship was significant or not needed to be carried out. Nonetheless, the results contradict that of a study by (Garaika, Siswoyo and Zainal ,2018) who found that corporate governance did not have any effect on performance of private universities in Indonesia, although performance was measured based on the balanced score card theory which was not adopted by the current study. 
It is concluded that combined effect of corporate governance components has a greater effect on performance of public universities in Kenya than isolated effect of transparent, adherence to management guidelines and public participation. The findings are consistent with the observations by Bechker and Garhart (1996) that synergetic effect rather than independent practice leads to competitive advantage.

\section{Correlation Results}

To establish the relationship between adherence to corporate governance practices and performance of Public Universities in Kenya. Pearson product moment correlation coefficients were used to establish whether a relationship existed between the level of adherence to corporate governance practices and performance of Public Universities. To start with the three dimensions of adherence to corporate governance practices were correlated with performance of Public Universities. All the correlation was deemed significant at a set value of 0.05 .

Table 8: Correlation Analysis Results

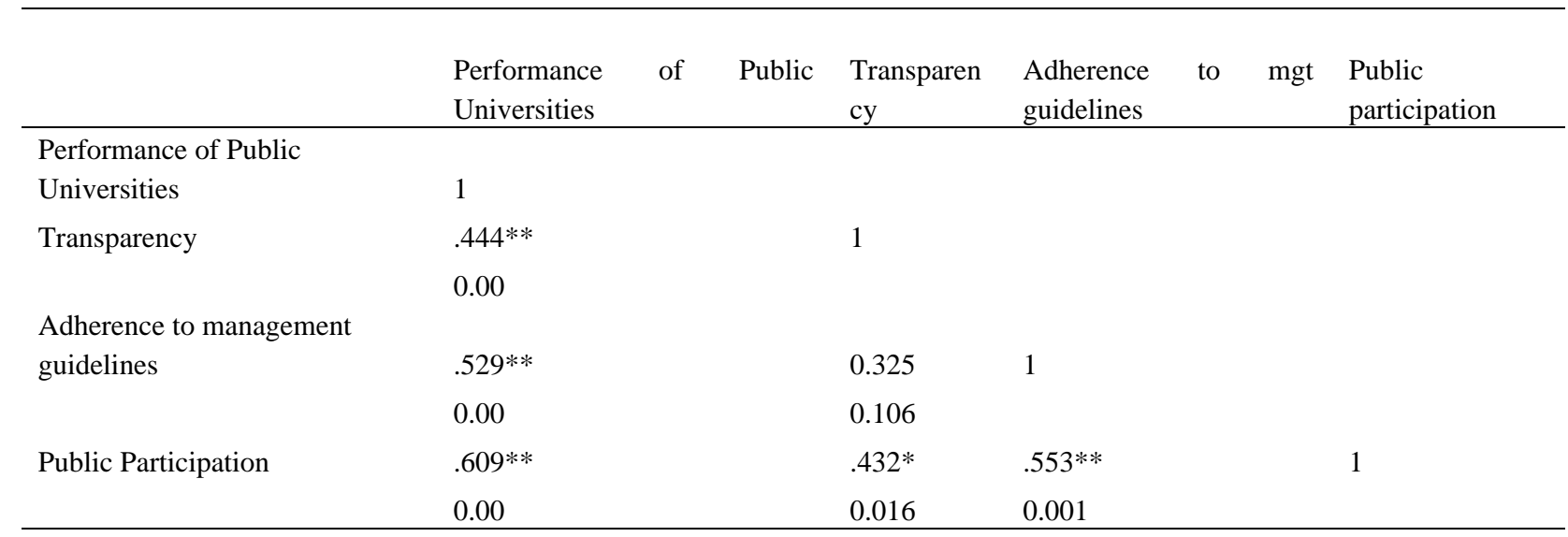

** Correlation is significant at the 0.01 level (2-tailed).

Source: Field data (2021)

Findings in Table 8 show that public participation had the highest positive relationship with performance of Public Universities $(\mathrm{r}=0.609, \mathrm{p}=0.00)$ followed by management adherence to guidelines $(\mathrm{r}=0.529, \mathrm{p}=0.00)$ and transparency had the lowest positive relationship with the performance of Public Universities $(\mathrm{r}=0.444, \mathrm{p}=0.00)$. These results show that there is a strong positive correlation between performance of public universities in Kenya and corporate governance. This implied that an increase in the level of the three dimensions of the of adherence to corporate governance leads to an increase in performance of Public Universities. Further, the results indicate that public participation is the most efficient way of improving performance of public universities for sustainability.

The correlations results concur the study by Okoko (2017) on the relationship between corporate governance and firm performance among 40 insurance companies in Kenya revealed using panel data that overall, there exists a relationship between corporate governance and firm performance. Further, Millet (2007) observed that the corporate governance policy had improved University and college quality, increased the ratio of applicants for admissions and further increased the number of faculty members in institutions of higher learning. (Nguyen and Lassibille 2008) found that a transparent system implemented among district and subdistrict schools in Madagascar caused an improvement in various observable performance measures among schools where monitoring was implemented.

\section{Conclusion}

Based on the findings of the study, it is concluded that first, public universities in Kenya that have not put in place mechanisms to adhere to corporate governance practices in matters of transparency, adherence to management guidelines and public participation to propel effective performance of the institutions should do so. Secondly, it is concluded that the practice of corporate governance among Kenyan universities is still generally weak and therefore require strengthening. Lastly, the study concludes that corporate governance is positively and significantly related to University performance and that corporate governance significantly affects performance of public universities in Kenya. Overall, the researcher concludes that corporate governance is a vital framework for effective performance of universities and therefore universities that practice effective corporate governance have the advantage of improving their performance significantly.

The study contributes to strategic management literature and specifically on corporate governance in Universities for superior performance by providing empirical evidence. Also, the study contributes to social network theory by examining the implication of corporate governance on transparency, adherence to management guidelines and public participation on matters affecting various stakeholders and performance of public Universities. 
The study strongly recommends that both the government and the individual university top managers in Kenya should seek to adhere and improve corporate governance practices through effective implementation of the various governance mechanisms established in the institutions of higher learning. In particular, the government through the Commission for University Education should enhance surveillance on university managers to ensure compliance with the Universities Act, 2012 and the Universities Standards and Guidelines, 2014 which provide corporate governance framework for all Universities in Kenya. The study further suggests that other studies be conducted among private universities in Kenya to determine if there are relational factors that influence the relationship between corporate governance and performance of private universities in Kenya.

\section{References}

Agiri, J. (2020). Corporate governance and performance of public universities in Kenya. Journal of Environmental Planning and Management, 60(12), 2133-2149.

Auditor General Report (2017,2018). Audited financial report for public Universities. http://www.aog.or.ke/.

Bhihimani, A. (2008). Ownership and control: Rethinking corporate governance for the twenty-first century. Washington, DC: Brookings Institution.

Cadbury Committee (1992), Cadbury Committee Report: Financial Aspects of Corporate Governance, Burgess Science Press, Basingstoke.

Cadbury Sir Adrian, Chairman (1992) Report of the Committee on the Financial Aspects of Corporate Governance. London: Gee.

Cappelli, P. (2008). Talent Management for the Twenty-First Century. Harvard Business Review. March, 74-81.

CIPD, (2010). The War On Strategies? Sustainability strategies Under Strategic Management in Uncertain Times. Available at http://www.cipd.co.uk/.

Collings, D. \& Mellahi, K. (2011). Strategic Sustainable Strategies: A Review and Research Agenda. Strategic Management Review. 19, 304-313.

Commission for University Education (CUE) (2018 and 2019). Academic Staff Qualifications.http://www.cue.or.ke/.

Conger, J. \& Fulmer R. (2014). Developing Your Leadership Pipeline. Harvard Business Review, 81(12).

Constitution of Kenya (2010). The Fourth Schedule. https://www.kenyaembassy.com/pdfs/the\%20constitution\%20of\%20kenya.pdf.

Corporate governance Council, (2007). Supporting Employee Development through Performance Management, Washington: Corporate Executive Board

Creswell, J.W. (2011). Research design. Qualitative, quantitative and mixed methods approaches. 3rd edition. USA: SAGE.

Donaldson, T. \& Preston, L. E (1995). The Stakeholder Theory of the Corporation; Concepts, Evidence and Implementations. Academy of Management Review 20 (1).

Eisenhardt, K.M. (1989) Agency Theory: An Assessment and Review. Academy of Management Review, 14(1)

FRC. (2010). Statement on global corporate governance principles. London: International Corporate Governance Network.

Freeman, R.E. (1984). Strategic Management: A stakeholder Approach. Pitman London.

Freeman, R.E. (2010) Strategic Management: A Stakeholder Approach, Cambridge University Press, New York.

Garaika, H, Siswoyo, H \& Zainal, M (2018). The Effects of Good University Governance and Organizational Culture toward Lecturer Performance and its Influence on Private Universities Performance in the City of Lampung. European Journal of Business and Management, 10(21).

Glesne, C., \& Peshkin, A. (2015). Becoming qualitative researchers. Thousand Oaks, CA: Sage.

Hastings, J, S, \& Weinstein, J, M. (2008). Information, School Choice, and Academic Achievement: Evidence from Two Experiments.

Hawley, J. P. \& Williams, A.T. (1996) Corporate Governance in the United States: The Rise of Fiduciary Capitalism, Working Paper, School of Economics and Business Administration, St Mary's College, Moraga, California.

Hove-Sibanda, P., Sibanda, K. \& Pooe, D., (2017). The impact of corporate governance on firm competitiveness and performance of small and medium enterprises in South Africa: A case of small and medium enterprises in Vanderbijlpark', Acta Commercii 17(1), https://doi.org/10.4102/ac. v17i1.446.

Kamau, G (2018). Corporate Governance, Agency Conflicts, Strategic Choices and Performance of Financial Institutions in Kenya. A Published PhD thesis, University of Nairobi, Kenya.

Kamau, G, Aosa, E, Machuki, V \& Pokhariyal, G (2018). Corporate Governance, Strategic Choices and Performance of Financial Institutions in Kenya. International Journal of Business and Management, 13(7), Canadian Center of Science and Education.

Lawal, B. (2012). Board Dynamics and Corporate Performance: Review of Literature, and Empirical Challenges. International Journal of Economics and Finance, 4, 22-35. http://dx.doi.org/ 10.18533/jefs. v4i02.21.

Letting, N., K (2011). Board of Directors' Attributes, Strategic Decision Making and Corporate Performance of Firms in the Nairobi Stock Exchange. A Published Doctoral Thesis, University of Nairobi, Kenya

Lewis, et. al, (2017). Talent Management: A Critical Review. Human Resource Management Review, 16: 139-154.

Lynch, D. (2011). Can Higher Education Manage sustainability? Available at http://www.insidehighered.com/views/2016/11/27/lyncy.

Makela, K., \& Bjorkman, I. E, M. (2010). How Do MNCS Establish Their Talent Pools? Influence On Individuals' Likelihood of Being Labelled as Talent. Journal of World Business, 45, 134-142. 
Mashonganyika, T., B (2015). The Relationship between Corporate Governance and Firm Performance in South Africa. A Published Masters Thesis, Wits Business School, Johannesburg.

McCann, J. (2004). The changing definition of organizational effectiveness. Human Resource Planning. 27(1), 17-30.

McNulty, J. K. (2010). When Positive Processes Hurt Relationships. Current Directions in Psychological Science, 19, 167-171. https://doi.org/10.1177/0963721410370298.

Mihyo. P. (2007). Staff Retention in African Universities and Links with Diaspora Study. Report for the Association for the Development of Education in Africa Working Group on Higher Education.

Millett, J.D. (1985), New Structure of Campus Power: Successes and Failures of Emerging Forms of Institutional Governance, Jossey Bass, San Francisco.

Monyoncho, R, M (2015) Perception of Corporate Governance Practices at the University of Nairobi. DBA, Africa Management Review, 5(1).

Munene, I (2008) Kenya's Universities Must Open up their Budgets to Scrutiny. Available at https://www.africanewshub.com/.../5911445.

Munene, J O. Otieno, W. (2005). Private higher education in Kenya, in N. V. Varghese Higher education and specialized training: new trends in higher education. Paris, UNESCO: International Institute for Educational Planning.

Muralidharan, K \& Sundararaman, V (2011). Teacher Performance Pay: Experimental Evidence from India, Mimeo UC San Diego. Journal of Political Economy, 119(1).

Mwebi, Simatwa. S (2017). Kenya: Private University Growth of Mixed Blessing. Retrieved December, 23, from http://www. Universityworldnews.com/article.php2.story. at 7.50am

Mwiria, K. \& Ngethe, N. Ngome C., Ouma-Odero, V. Wawire D. \& D. Wesonga (2014) Public University reform in Kenya: Mapping the key changes in the last decade in Public and private Universities in Kenya. Oxford: James Curry Ltd.

Mwiria, K. M. (2016). Public \& Private Universities in Kenya. New Challenges, Issues \& Achievements. Nairobi: East African Educational Publishers.

Nafukho, F. (2008). Consensus building, dialogue and spirituality principles of the learning organization paradigm: implications for Kenya's public service reform agenda, Journal of Third World Studies, 25(2),153-75.

Nair, C., S., Wayland, C, \& Soediro, S. (2005). Evaluating the Student Experience: A Leap into the Future. Paper Presented at The 2005 Australasian Evaluations Forum: University Learning and Teaching: Evaluating and Enhancing the Experience, UNSW, Sydney, 28-29 November.

Ndiwalana, G, Ssekakubo, J \& Lwanga, F (2017). Corporate Governance and the Financial Performance of Savings, Credit and Corporative Societies. International Research Journal of Arts and social Science Vol. 3(3).

Ndwiga, E., K (2018). Corporate Governance, Strategy Implementation, Industry Competition and Performance of Companies Listed on Nairobi Securities Exchange. A Published PhD thesis, University of Nairobi, Kenya.

Nguyen, W. G. (2008). University mergers in South Africa ( $8^{\text {th }}$ ed.). Mason, HO: Cengage Learning.

Nunnally, J.C. (1978) Psychometric theory. 2nd Edition, McGraw-Hill, New York.

Odhiambo, G. C. (2014). A Role of Institutional Managers in Quality Assurance: Reflections On Kenya's University Education Australian Journal of Business and Management Research Vol.1 No.2 May-2011.

Okoko, P., A (2017). Relationship between Corporate Governance and the Performance of Insurance Companies in Kenya. A Published Masters thesis, University of Nairobi, Kenya.

Petra, T. (2006) The Charity: Pivotal Social Policy Role. International Journal of Sociology and Social Policy. 14(4).

Rockoff, J \& Turner, J (2010) Short-Run Impacts of Accountability on School Quality. American Economic Journal: Economic Policy. 2(4)

Scullion, H. \& Collings D.G. (2010). Global Talent Management. Journal of World Business, 45, 105-108.

Shabbir, A., \& Padget, C (2005). The UK Code of Corporate Governance. Link between Compliance and Performance. Working paper, ICMA Centre, University of Reading.

Tricker, R. I, 1978, The Independent Director - a study of the non-executive director.

Tusubira, N., F \& Nkote, I., N (2013). Corporate Governance in Private Universities: Financial Performance Perspective. Journal of Business Law and Ethics, Vol. 1 No. 1. American Research Institute for Policy Development.

Universities Grant Commission (2018) Total Number of Universities in the Country as on 2.7.2015. Available at https://www.ugc.ac.in/oldpdf/alluniversity.pdf.

Universities UK (2018) Patterns and Trends in UK Higher Education. Available at www.universitiesuk.ac.uk/facts.../patterns-andtrends-uk-higher-education-2015.

Vinten G (2001) Ethical Aspects of Mergers and Acquisitions in Europe, in Business Ethics in a New Europe, Kluwer Academic Publishers, 114- 137.

Visconti, R. (2019). Equity retention and social network theory in equity crowd funding. https://doi.org/10.2139/ssrn.2654325

Waduge, C., S., S., L (2011). Governance and Performance: An Empirical Study of Australian Universities. A Published PhD thesis, Victoria University, Melbourne.

Wangenge-Ouma, G., Lutomiah, A. and Langa, P. (2015). Academic incentives for knowledge production in Africa. Case studies of Mozambique and Kenya, in Cloete, N. and Maassen, P. (Eds), Knowledge Production and Contradictory Functions in African Higher Education, African Minds, Cape Town, 128-147. 
Wasserman, S., Faust, K. (1997) Social network analysis: Methods and applications, Cambridge University Press, New York World Bank (2017) Tertiary Education Overview. Available at www.worldbank.org/en/topic/tertiaryeducation.

Yamane, T (1967). Statistics. An Introductory Analysis, 2nd Ed., New York: Harper and Row

Publisher's Note: SSBFNET stays neutral with regard to jurisdictional claims in published maps and institutional affiliations.

\section{(9) (1)}

(C) 2021 by the authors. Licensee SSBFNET, Istanbul, Turkey. This article is an open access article distributed under the terms and conditions of the Creative Commons Attribution (CC BY) license (http://creativecommons.org/licenses/by/4.0/).

International Journal of Research in Business and Social Science (2147-4478) by SSBFNET is licensed under a Creative Commons Attribution 4.0 International License. 